\title{
SIGNIFICANCE OF THE CHANGES IN THE STRUCTURE OF THE ANOCOCCYGEAL LIGAMENT AS A POSSIBLE CAUSE OF THE DEVELOPMENT OF CHILDREN' DEFECATION DISORDERS
}

\author{
Konoplitskyi V. S., Lukiianets O. O.
}

\section{INTRODUCTION}

Morphological study of the state of the tissues of the perineum and distal colon's parts (DCP), the examination of the anatomical features of their muscles and fascial-cellular spaces from the position of macro- and microscopic structure in modern medicine is relevant and promising, as it can provide an comprehensive answer and fully discover the versatility of their anatomical functionality ${ }^{1}$.

In adults, the coccyx usually consists of three to five vertebrae, which are connected by a cartilage disc to the fifth sacral vertebra. Sinostasis of the coccygeal vertebrae begins approximately at the age of twelve from bottom to top. Muscles and ligaments that participate in the functioning of the urinary system and the DCP are attached to the coccyx. The pubiccoccygeal, iliac-coccygeal and coccygeal muscles form the lift muscle of the anus, and the anococcygeal ligament is interwoven into the fibers of the rectal sphincter. The anatomical features of the female pelvis include the fact that the sacral bone along with the coccyx is deflected more to the back, so that the coccyx is located more superficially than in men. The angle between the sacrum and the coccyx is normally ${ }^{2} 150 \pm 3.7^{\circ}$.

The anatomic-functional unity of the fasciae, ligaments and muscles of the DCP forms an elastic suspended structural system that promotes the formation of natural bends (ano-rectal and sigmo-rectal angles) responsible for the implementation of both the normal act of defecation and the function of physiological abstention. In case of any component disorder of this DCP system, or change in the size of the sacroiliac angle, factors that contribute to the formation of conditions for dysfunction of the rectum and pelvic bottom appear. The applied fascias value is conditioned that they, being the

\footnotetext{
${ }^{1}$ Васильчишина А.В., Хмара Т.В., Васильчишина Я.М. Перинатальна анатомія сідничної ділянки. Чернівці : Медуніверситет, 2017. 132 с.

2 Бабкин А.В., Егорова 3.В. Современные подходы к лечению кокцигодинии. ARS MEDICA. 2012. № 4, т. 59. С. 6
} 
components of the soft skeleton, are the flexible extension of the skeleton, being the support for the muscles and pelvic organs, performing primarily mechanical functions. Also, the ligaments and fasciae of the rectum determine the rigidity of its spacious position, which contribute to the deformation of the DCP position during the destruction of the anococcygeal ligament (ACL), as only the muscles remain in the restraint system, without the counterweight, which changes the size of the ano-rectal angle (ARA) and deform the direction of the channel of the anus. In the modern specialized literature, there is only fragmentary data on the macro- and microscopic structure of the ACL in the age aspect ${ }^{3}$. Therefore, the study of the characteristics of the structure and maturity of the ACL as the separate organ in the fetus are relevant in the sense of understanding of its meaning and function.

The study of the typical anatomy of the peritoneal region was performed on 5 preparations of fetuses of 6-7 months of 186.0-270 mm of parietal coccygeal length (PCL) of a person and newborns without external signs of anatomic abnormalities or congenital malformations. The age structure of the objects of research is determined taking into account the maturity and potential vitality of the organism (fig. 1,2).

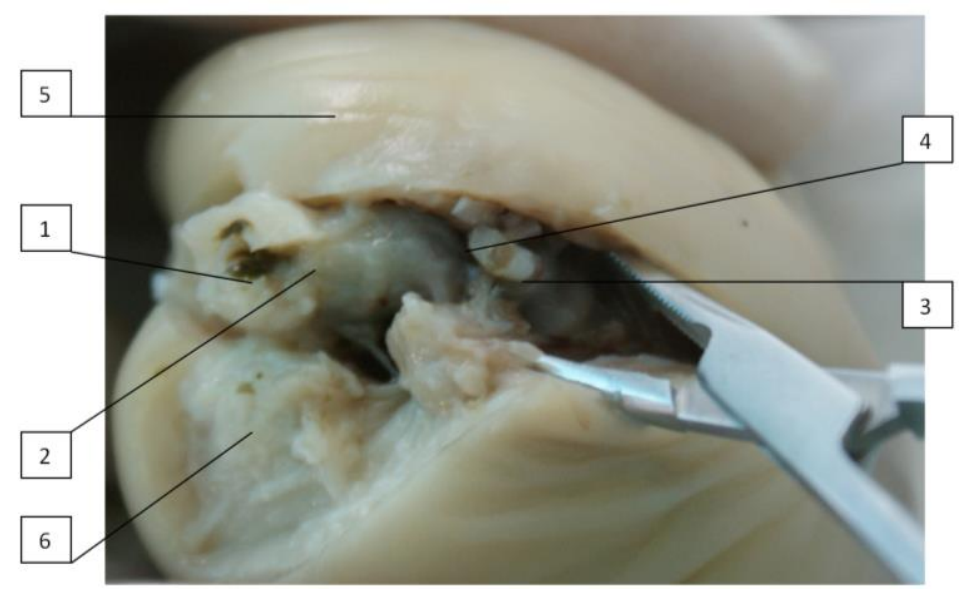

Fig. 1. Perineal area of the fetus $230,0 \mathrm{~mm}$ PLC. Macropreparation. $2 \times$ magnification. 1 - anus with a remote fragment of the external anus muscle contactor; 2 - rectum; 3 - coccyx; 4 is a fragment of an anococcygeal ligament; 5 - right buttock area; 6 - lumbar - buttock

${ }^{3}$ Клінічна анатомія прямої кишки та відхідника / Слободян О.М., Костюк Г.Я., Дуденко В.Г. та ін. Чернівці, 2015. 112 с. 




Fig. 2. Fragment of the perineal section of the fetus $230,0 \mathrm{~mm}$ PLC. Micropreparation. 1 - is a fragment of the coccygeal bone, which at the present period of fetal gestation, is represented by the cartilage with an element of fibrous layer of periosteum (1A); 2 - mucous membrane of the IC (intestinal crypts); 3 - a muscular plate of a mucous membrane; 4 - submucosal base; 5 - the inner layer of the muscle; 6 - is the outer layer of the muscle; 7 - intermuscular nerve ganglia; 8 - is a fragment of the anococcygeal junction with elements of loose connective tissue and the presence of vessels in it; 9 - is a connective tissue membrane. Van Gizon coloring. $\times 100$

The presented information of morphological researches testifies to the fact that already at the beginning of the third trimester of the prenatal fetal development, all structural elements of its peritoneal area are completely formed in an anatomical sense and can perform their physiological functions.

1. Model presentation of the dimension change in the anorectal angle under the influence of loss of the function of anococcygeal ligament

The application of the wave principle, such as when creating a running wave in an environment, is ineffective for organizing of the number of processes or operations with viscous plastic environments. To overcome 
these difficulties, it was suggested to use the effect of converting elasticplastic resistance into a viscous environment. The effect is observed in the conditions if to the moving object in a viscous plastic environment is provided with an additional displacement, which form some angle with the main direction of motion ${ }^{4}$.

In a model presentation of the promotion of the contents of the rectum as a wave process under the action of peristaltic motions, the environment moving through the channel of the flexible container, we will consider viscous - plastic.

Due to the reflex contractions (deformation) of the intestinal walls, a surface wave will flow through them, which will give the additional motion to the environment, determine the shape and parameters of this movement.

To study such a wave, the superposition principle was used and a moving and fixed coordinate system $\mathrm{O}, \mathrm{x}, \mathrm{y}, \mathrm{z}$, and $\mathrm{O}$ x y z were introduced (fig. 3).

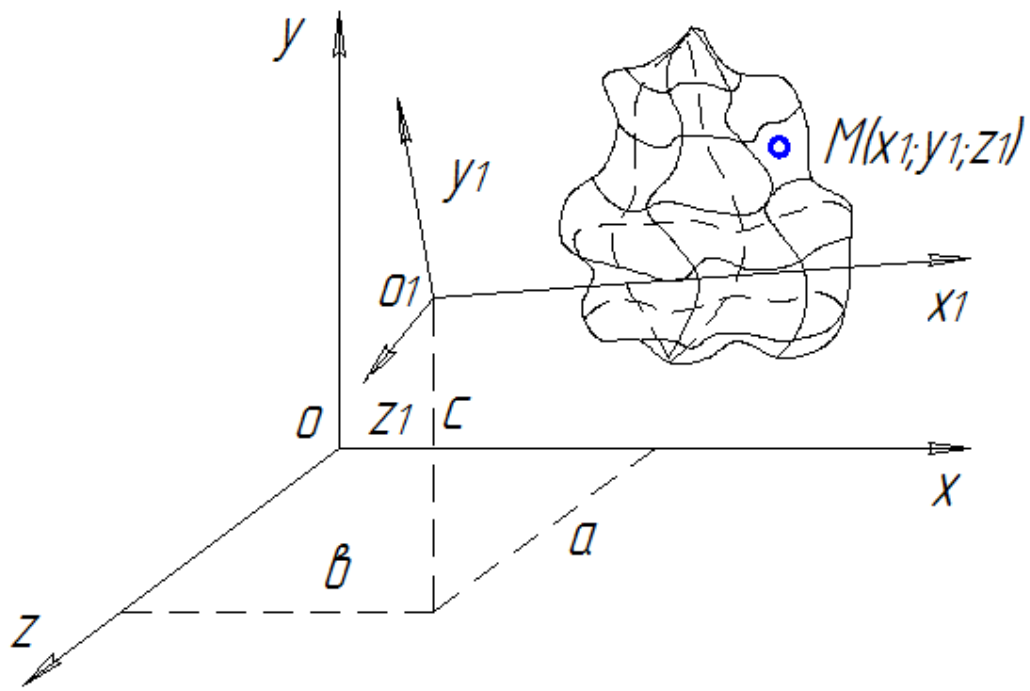

Fig. 3. The surface wave of deformation on the surface of the colon

The patient's coccyx was selected for the conditional fixed positioning axis, in relation to which the anorectal angle $\lambda$ change is taking place.

${ }^{4}$ Конопліцький В.С. Модель хвильового процесу вмісту прямої кишки під дією перистальтичних рухів. Наукові записки міжнародного гуманітарного університету. 2014. Вип. 21, Ч. II. 16. С. 185. 
The wave surface given by the equation in the moving coordinates is:

$$
z_{1}=f_{1}\left(x, y_{1}\right),
$$

where $y_{1}=f_{2}\left(x_{1}\right),\{x, y\}-$ area of definition $z_{1}$ :

$$
\left\{\begin{array}{l}
x=a+x_{1} \cdot \cos \alpha_{1}+y_{1} \cdot \cos \alpha_{2}+z_{1} \cdot \cos \alpha_{3} \\
y=b+x_{1} \cdot \cos \alpha_{1}+y_{1} \cdot \cos \alpha_{2}+z_{1} \cdot \cos \alpha_{3}, \\
z=c+x_{1} \cdot \cos \alpha_{1}+y_{1} \cdot \cos \alpha_{2}+z_{1} \cdot \cos \alpha_{3}
\end{array}\right.
$$

where $a, b, c, \alpha_{i}, \beta_{i}, \gamma_{i}(i=1,2,3)$ - time functions.

The parameters $a$ and $b$ will be limited by the dimensions of the flexible resiliently-elastic element in the horizontal section; parameter $c$ - the distance between the projections (supports) of the relief of the mucous membrane inside the rectum.

If the contraction of the elastic walls occurs with the period $\mathrm{T}$, then the frequency of peristaltic contractions will be equal to- $v$, at what:

$$
v=\frac{1}{T} ; \omega=\frac{2 \cdot \pi}{T}
$$

Then

$$
\alpha_{i}=\frac{2 \cdot \pi}{T} \cdot t+\phi_{1 \cdot i} ; \beta_{i}=\frac{2 \cdot \pi}{T} \cdot t+\phi_{2 \cdot i} ; \gamma_{i}=\frac{2 \cdot \pi}{T} \cdot t+\phi_{3 \cdot i}, i=1,2,3,
$$

where $\phi_{1 \cdot i}, \phi_{2 \cdot i}, \phi_{3 \cdot i}$ - the initial phases of the moving environment.

The movement of material in such a cavity can be divided into several variants: the first movement resembles the relocation of the transverse wave in the elastic environment (fig. 4 6); the second is the relocation in the conditions of radial wave appearing to the peristaltic movement (fig. 4 в). In addition, the presence of elastic supports allows to identify the researched relocation with movement in the spiral directions (fig. 4 a).

Consider the movement of the viscous-plastic environment in the intestinal canal when it is affected by: gravity G, the internal friction force $\mathrm{Ft}$, the adhesion force to the walls Fpr, the force of normal reaction from the walls $\mathrm{N}$, and the pressure from the walls, arising from their reflex reductions Fp. (fig. 5). 

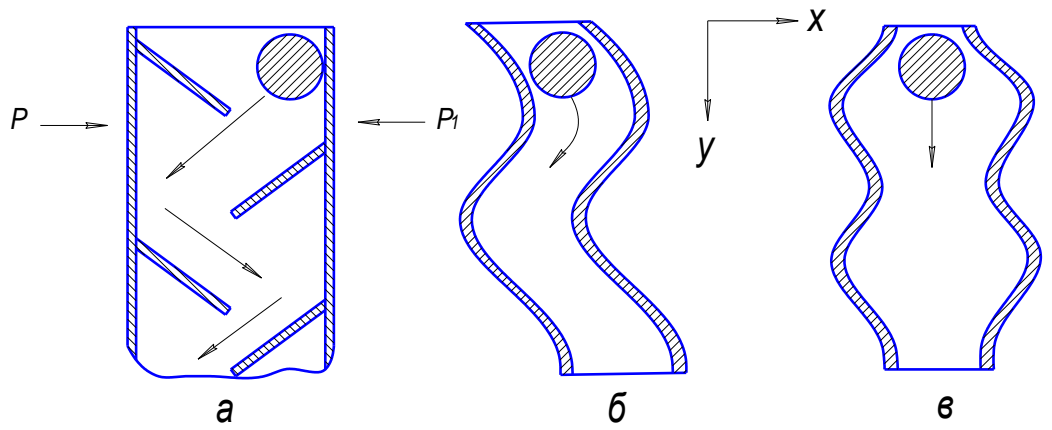

Fig. 4. Variants of movement of the researched waving system: a - relocation's direction with the movement on the spiral directions; $\sigma$ - relocation's direction of the transverse wave in the elastic environment; B - relocation's direction during the radial wave under the influence of the peristaltic movement

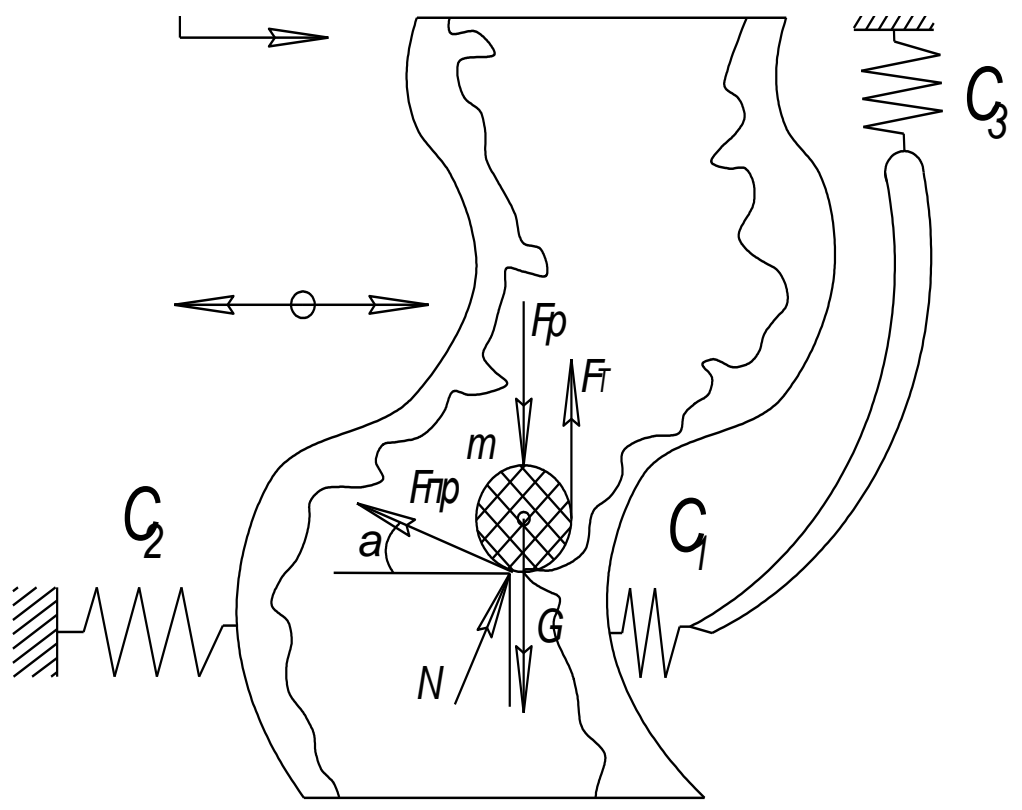

Fig. 5. Calculation scheme of the system of moving the contents of the rectum 
The elastic forces of this system contain 3 components: from the coccyx to the rectum and $F_{n 1}=x \cdot C_{1}$ and $F_{n 3}=y \cdot C_{3}$; from the abdomen to the rectum $F_{n 2}=x \cdot C_{2}$ Write down the differential equations of motion of the element of the environment in the projections on the coordinate axes (consider that the horizontal movement is the same throughout the whole section):

$$
\left\{\begin{array}{l}
\ddot{m}=G-F_{T}-F_{n p} \cdot \sin \alpha-N \cdot \cos \alpha+F_{P}+F_{n 1}-F_{n 2} \\
\ddot{m}=N \cdot \sin \alpha-F_{n p} \cdot \cos \alpha-F_{n 4}
\end{array}\right.
$$

Determine the forces that are included in the system of equations (4). The force of gravity is:

$$
G=m \cdot g,
$$

where $m$ - mass of the environment.

Force of the internal viscous friction will find by the Stocks formula:

$$
F_{T}=6 \cdot \pi \cdot \eta \cdot R \cdot \dot{x}
$$

where $\eta$-environment viscous; $R$ - average radius of the mass element of the environment; $\dot{x}$-movement speed of the environment element.

The adhesion force will found by the formula:

$$
F_{n p}=\lambda \cdot S_{k}
$$

where $\lambda$-adhesion factor; $S_{k}$ - area of the element's environment and wall contact.

In the general case of adhesion to the walls also includes the friction between the environment and the walls, so we it can be written down:

$$
F_{n p}=f \cdot N
$$

From what we can find the normal walls' reaction:

$$
N=\frac{F_{n p}}{f}=\frac{\lambda \cdot S_{k}}{f},
$$

where $f$ - the coefficient of friction between the material and the intestinal walls. Force $F_{P}$ appears as the result of the material speed change from the contractions of the intestinal conveyor, that's why: 


$$
F_{P}=m \cdot \frac{\Delta v}{\tau},
$$

where $\tau$ - period of one contraction. This speed's change we find from the Bernoulli law and the equation of continuity of the environment flow:

$$
\begin{aligned}
p_{1}+\rho \cdot g \cdot h+\frac{\rho \cdot v_{1}^{2}}{2} & =p_{2}+\rho \cdot g \cdot h+\frac{\rho \cdot v_{2}^{2}}{2}, \\
v_{1} \cdot S_{1} & =v_{2} \cdot S_{2}
\end{aligned}
$$

where $p_{1}$ - pressure on the wall before its contraction; $p_{2}$ - pressure on the wall during its contraction; $S_{1}=\frac{\pi \cdot d_{1}^{2}}{4} ; S_{2}=\frac{\pi \cdot d_{2}^{2}}{4}-$ cross-sectional area;

$\rho \cdot g \cdot h$ - static pressure on the material; $\rho$ - material density;

$v_{1}=v_{0}$ - initial material speed; $v_{2}$ - finite material speed.

Transforming the formula data we get:

$$
\Delta v=\frac{\Delta \rho \cdot d_{2}^{2}}{\rho \cdot v_{0} \cdot d_{1}^{2}}
$$

This way

$$
F_{P}=\frac{m \cdot \Delta \rho \cdot d_{2}^{2}}{\tau \cdot \rho \cdot v_{0} \cdot d_{1}^{2}}
$$

Considering the obtained values of the forces, equation (11) takes the form:

$$
\left\{\begin{array}{l}
\ddot{x}=g-\frac{6 \cdot \pi \cdot \eta \cdot R}{m} \cdot \dot{x}-\frac{\lambda \cdot S_{k}}{m} \cdot \sin \alpha-\frac{\lambda \cdot S_{k}}{m \cdot f} \cdot \cos \alpha+\frac{\Delta p_{x} d_{2}^{2}}{\tau \cdot \rho \cdot v_{0} \cdot d_{1}^{2}}+\frac{x}{m} \cdot\left(C_{1}-C_{2}\right) \\
\ddot{y}=\frac{\lambda \cdot S_{k}}{m f} \cdot \sin \alpha-\frac{\lambda \cdot S_{k}}{m} \cdot \cos \alpha+\frac{\Delta p_{y} d_{2}^{2}}{\tau \cdot \rho \cdot v_{0} \cdot d_{1}^{2}}-\frac{y C_{3}}{m}
\end{array}\right.
$$

or:

$$
\left\{\begin{array}{l}
\ddot{x}+\frac{6 \cdot \pi \cdot \eta \cdot R}{m} \cdot \dot{x}+x \cdot\left(C_{2}-C_{1}\right)=\frac{\Delta p_{x} d_{2}^{2}}{\tau \cdot \rho \cdot v_{0} \cdot d_{1}^{2}}-\frac{\lambda \cdot S_{k}}{m} \cdot\left(\sin \alpha+\frac{\cos \alpha}{f}\right) \\
\ddot{y}+\frac{6 \cdot \pi \cdot \eta \cdot R}{m} \cdot \dot{y}+y \cdot C_{3}=\frac{\Delta p_{y} d_{2}^{2}}{\tau \cdot \rho \cdot v_{0} \cdot d_{1}^{2}}-\frac{\lambda \cdot S_{k}}{m} \cdot\left(\sin \alpha-\frac{\cos \alpha}{f}\right)
\end{array}\right.
$$

where $\alpha$-the angle of the ledges (supports) inside the conveyor to the horizontal. 
Performing the mathematical processing of the obtained equations of motion, we use the following values of the parameters: the coefficient of adhesion ( $\left.\lambda=2000 \mathrm{H} / \mathrm{m}^{2}\right)$; friction coefficient $(f=0,15)$; incline angle $\left(\alpha=5^{0}\right)$, mass $(m=0,15 \mathrm{~kg})$; the viscosity of the environment $\left(\eta=36 \mathrm{H} \mathrm{s} / \mathrm{m}^{2}\right)$; radius $(R=0,028 \mathrm{~m})$; area $\left(S_{k}=\pi \cdot R^{2} \cdot l_{k} \mathrm{~m}^{2}\right)$; pressure $\left(\Delta p_{x}=490,3 \cdot \sin (\omega \cdot t)\right.$ та $\Delta p_{y}=490,3 \cdot \cos (\omega \cdot t \mathrm{~Pa})$; diameter $\left(d_{1}=0,06\right.$ and $\left.d 2=0,03 \mathrm{~m}\right)$; density ( $\left.\rho=600 \mathrm{~kg} / \mathrm{m}^{3}\right)$; speed $\left(v_{0}=0,011 \mathrm{~m} / \mathrm{s}\right)$; period $(\tau=15 \mathrm{~s})$; frequency of the contractions $\left(\omega=1,033 \mathrm{~s}^{-1}\right)$; stiffness of the coccyx in the horizontal direction ( $C_{1}=50 \mathrm{H} / \mathrm{m}$ ); stiffness of the ligament between the coccyx and the rectum $\left(C_{2}=40 \mathrm{H} / \mathrm{m}\right)$; stiffness of the coccyx in the vertical direction $\left(C_{1}=60 \mathrm{H} / \mathrm{m}\right)$.

$$
\begin{aligned}
& \left\{\begin{array}{l}
\ddot{x}+\frac{6 \cdot \pi \cdot \eta \cdot R}{m} \cdot \dot{x}+x \cdot\left(C_{2}-C_{1}\right)=\frac{\Delta p_{x} d_{2}^{2}}{\tau \cdot \rho \cdot v_{0} \cdot d_{1}^{2}}-\frac{\lambda \cdot S_{k}}{m} \cdot\left(\sin \alpha+\frac{\cos \alpha}{f}\right) \\
\ddot{y}+\frac{6 \cdot \pi \cdot \eta \cdot R}{m} \cdot \dot{y}+y \cdot C_{3}=\frac{\Delta p_{y} d_{2}^{2}}{\tau \cdot \rho \cdot v_{0} \cdot d_{1}^{2}}-\frac{\lambda \cdot S_{k}}{m} \cdot\left(\sin \alpha-\frac{\cos \alpha}{f}\right)
\end{array}\right. \\
& \left\{\begin{array}{l}
\ddot{x}+\alpha_{x} \cdot \dot{x}+x \cdot\left(C_{2}-C_{1}\right)=A_{x} \cdot \sin (\omega \cdot t)-B_{1} \\
\ddot{y}+\alpha_{y} \cdot \dot{y}+y \cdot C_{3}=A_{y} \cdot \cos (\omega \cdot t)-B_{2}
\end{array} \quad B_{2}=\frac{\lambda \cdot S_{k}}{m} \cdot\left(\sin \alpha+\frac{\cos \alpha}{f}\right)\right.
\end{aligned}
$$

We solve equation (14) by the Cauchy method for linear miscellaneous differential equation with constant coefficients:

$$
\ddot{x}+a_{x} \cdot \dot{x}+k x=A_{x} \cdot \sin (\omega \cdot t)-B_{1},
$$

where $a_{x}=a_{y}=\frac{6 \cdot \pi \cdot \eta \cdot R}{m}$ coefficient of dissipation of the peristaltic movement of the system in the axis direction $O X, O Y$;

$$
A_{x}=\frac{\Delta p_{x} d_{2}^{2}}{\tau \cdot \rho \cdot v_{0} \cdot d_{1}^{2}}-\frac{\lambda \cdot S_{k}}{m} \text { - the specific module of the compelling force }
$$
of the peristaltic movement of the system. General solution of the equation present in the form:

$$
x=x^{*}+\bar{x}
$$

$x^{*}$ - general solution of the corresponding homogeneous equation;

$\bar{x}$ - partial solution of the equation. 
Have:

$$
x^{*}=e^{-\alpha_{x} \cdot t}+C_{1} \cos \left(\frac{-\alpha_{x}-\sqrt{\alpha_{x}^{2}-4 k_{x}}}{2} \cdot t\right)+C_{2} \sin \left(\frac{-\alpha_{x}+\sqrt{\alpha_{x}^{2}-4 k_{x}}}{2} \cdot t\right)
$$

May $\bar{x}=A \cos \omega t+B \sin \omega t+C$,

Then

$$
x^{*}=-A \omega \sin \omega t+B \omega \cos \omega t ; \bar{x}=-A \omega^{2} \cos \omega t-B \omega^{2} \sin \omega t
$$

Using the properties of equations with constant coefficients, we construct and solve a small system of equation:

$$
\begin{aligned}
& -A \omega^{2} \cos \omega t-B \omega^{2} \sin \omega t-\alpha_{x} A \omega \sin \omega t+\alpha_{x} B \omega \cos \omega t+ \\
& +k_{x} A \cos \omega t+k_{x} B \sin \omega t+C=A_{x} \sin \omega t-B_{1} \quad ; \\
& \left(-A \omega^{2}+\alpha_{x} B \omega+k_{x} A\right) \cos \omega t+\left(-B \omega^{2}-\alpha_{x} A \omega+k_{x} B\right) \sin \omega t+C= \\
& =A_{x} \sin \omega t-B_{1} \\
& \left\{\begin{array} { l } 
{ - A \omega ^ { 2 } + \alpha _ { x } B \omega + k _ { x } A = 0 } \\
{ - B \omega ^ { 2 } - \alpha _ { x } A \omega + k _ { x } B = A _ { x } }
\end{array} \Rightarrow \left\{\begin{array}{l}
A\left(k_{x}-\omega^{2}\right)+\alpha_{x} B \omega=0 \\
B\left(k_{x}-\omega^{2}\right)-\alpha_{x} A \omega=A_{x}
\end{array} \Rightarrow\right.\right. \\
& \Rightarrow\left\{\begin{array}{l}
B=-\frac{k_{x}-\omega^{2}}{\alpha_{x} \omega} A \\
\frac{\left(k_{x}-\omega^{2}\right)^{2}-\alpha_{x}^{2} \omega^{2}}{\alpha_{x} \omega} A=A_{x}
\end{array}\right. \\
& \left\{\begin{array}{l}
A=\frac{A_{x} \alpha_{x} \omega}{\left(k_{x}-\omega^{2}\right)^{2}-\alpha_{x}^{2} \omega^{2}} \\
B=-\frac{A_{x}\left(k_{x}-\omega^{2}\right)}{\left(k_{x}-\omega^{2}\right)^{2}-\alpha_{x}^{2} \omega^{2}}
\end{array}\right.
\end{aligned}
$$

Then:

$$
\bar{x}=\frac{A_{x} \alpha_{x} \omega}{\left(k_{x}-\omega^{2}\right)^{2}-\alpha_{x}^{2} \omega^{2}} \cos \omega t-\frac{A_{x}\left(k_{x}-\omega^{2}\right)}{\left(k_{x}-\omega^{2}\right)^{2}-\alpha_{x}^{2} \omega^{2}} \sin \omega t-B_{1}
$$




$$
\begin{gathered}
x=e^{-\alpha_{x} \cdot t}+C_{1} \cos \left(\frac{-\alpha_{x}-\sqrt{\alpha_{x}^{2}-4 k_{x}}}{2} \cdot t\right)+C_{2} \sin \left(\frac{-\alpha_{x}+\sqrt{\alpha_{x}^{2}-4 k_{x}}}{2} \cdot t\right)+ \\
+\frac{A_{x} \alpha_{x} \omega}{\left(k_{x}-\omega^{2}\right)^{2}-\alpha_{x}^{2} \omega^{2}} \cos \omega t-\frac{A_{x}\left(k_{x}-\omega^{2}\right)}{\left(k_{x}-\omega^{2}\right)^{2}-\alpha_{x}^{2} \omega^{2}} \sin \omega t-B_{1}
\end{gathered}
$$

Similarly to the above method, we obtain the offset for the vertical component:

$$
\begin{gathered}
y=e^{-\alpha_{y} \cdot t}+C_{3} \cos \left(\frac{-\alpha_{y}-\sqrt{\alpha_{y}^{2}-4 k_{y}}}{2} \cdot t\right)+C_{2} \sin \left(\frac{-\alpha_{y}+\sqrt{\alpha_{y}^{2}-4 k_{y}}}{2} \cdot t\right)+ \\
+\frac{A_{y} \alpha_{y} \omega}{\left(k_{y}-\omega^{2}\right)^{2}-\alpha_{y}^{2} \omega^{2}} \sin \omega t-\frac{A_{y}\left(k_{y}-\omega^{2}\right)}{\left(k_{y}-\omega^{2}\right)^{2}-\alpha_{y}^{2} \omega^{2}} \cos \omega t-B_{2}
\end{gathered}
$$

In the result of mathematical analysis, the following graphical dependencies were obtained in the MathCAD software environment (fig. 6). For the obtained graphical interpretations, we use the linearization method.

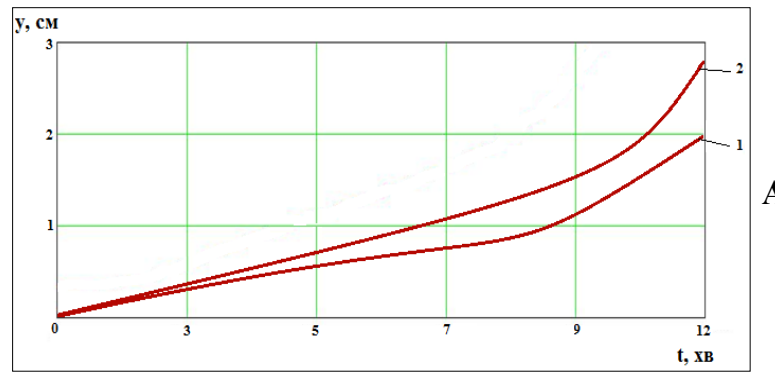

A

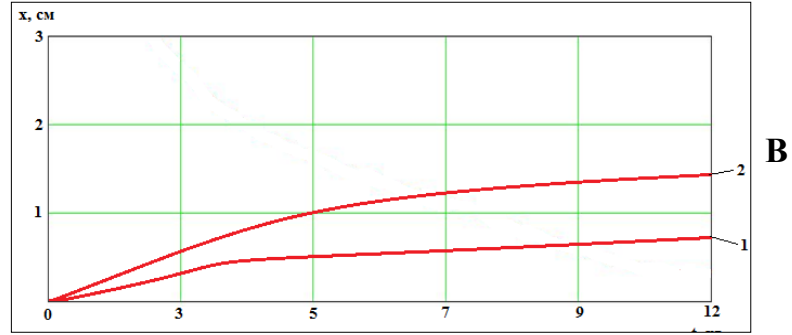

Fig. 6. A - value of the anorectal displacement along the axis OY: 1 - without bond $\mathrm{C}_{2} ; 2$ - without bond $\mathrm{C}_{1} ; \mathrm{B}$ - value of the anorectal displacement along the axis $\mathrm{OX}: 1$ - without bond $\mathrm{C}_{2}$;

$$
2 \text { - without bond } C_{1}
$$


Analysis of the obtained graphical interpretations showed that the value of displacement of the rectal passage of the rectum is highly dependent on the $\mathrm{C} 2$ bond deprivation and is along the axis $\mathrm{OY}-2,8 \mathrm{sm}, \mathrm{OX}-1,4 \mathrm{sm}$.

To determine the change in the anorectal angle $\lambda$, we take into account the trigonometric properties of triangles, in which the founded displacements according to the axis $\mathrm{OX}$ and $\mathrm{OY}$ are used as perpendicular and adjacent catheters (fig. 7).

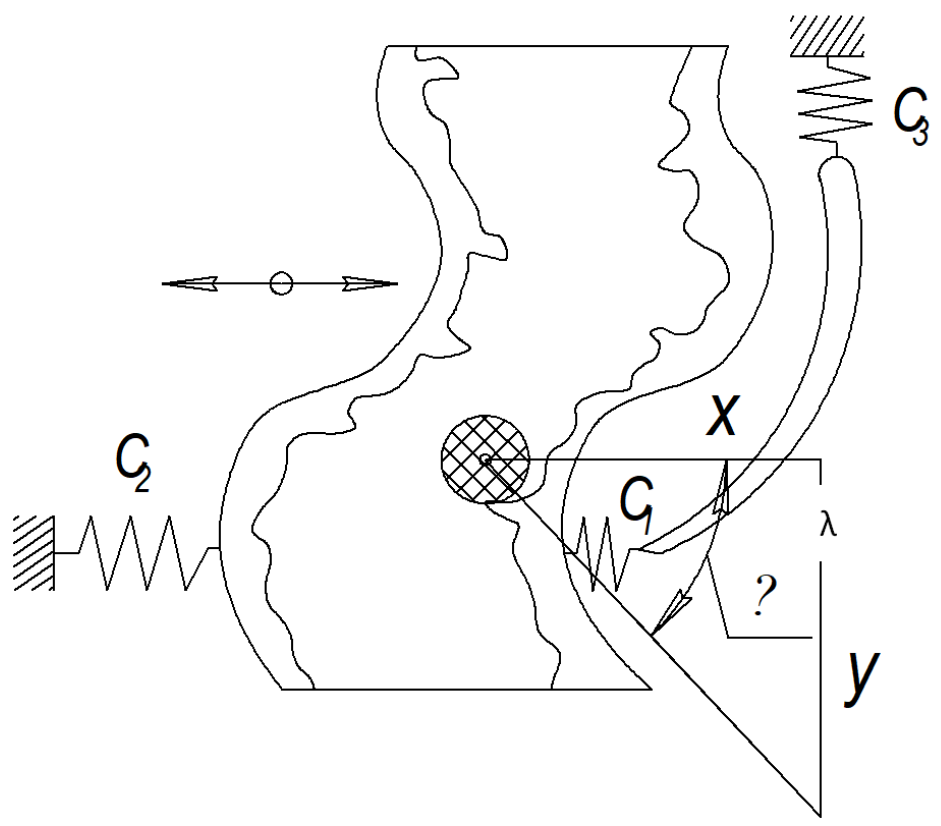

Fig. 7. Scheme of determination of anorectal angle change

$$
\operatorname{tg} \lambda=x / y \rightarrow \lambda=\operatorname{arctg}(x / y)=\operatorname{arctg}(2.8 / 1.4)=63^{\circ}
$$

The analysis showed that the deprivation of the previous component, the connection between the coccyx and the rectum $\mathrm{C}_{2}$, the ARA will change to a value that can reach digitally $63^{\circ}$, which is presented in the form of a biomechanical scheme in the (fig. 8). 


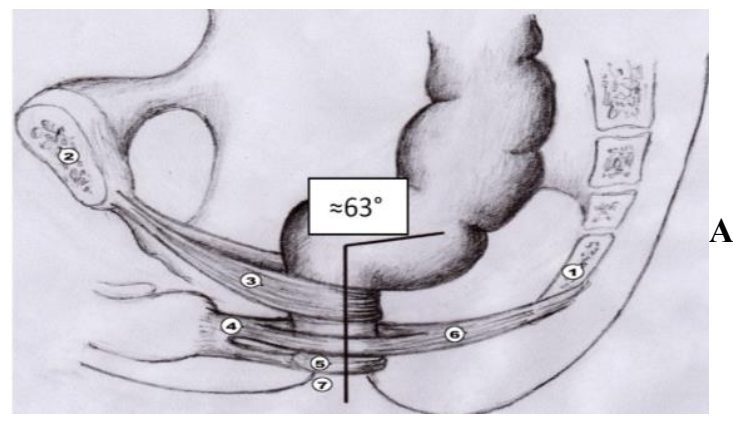

A

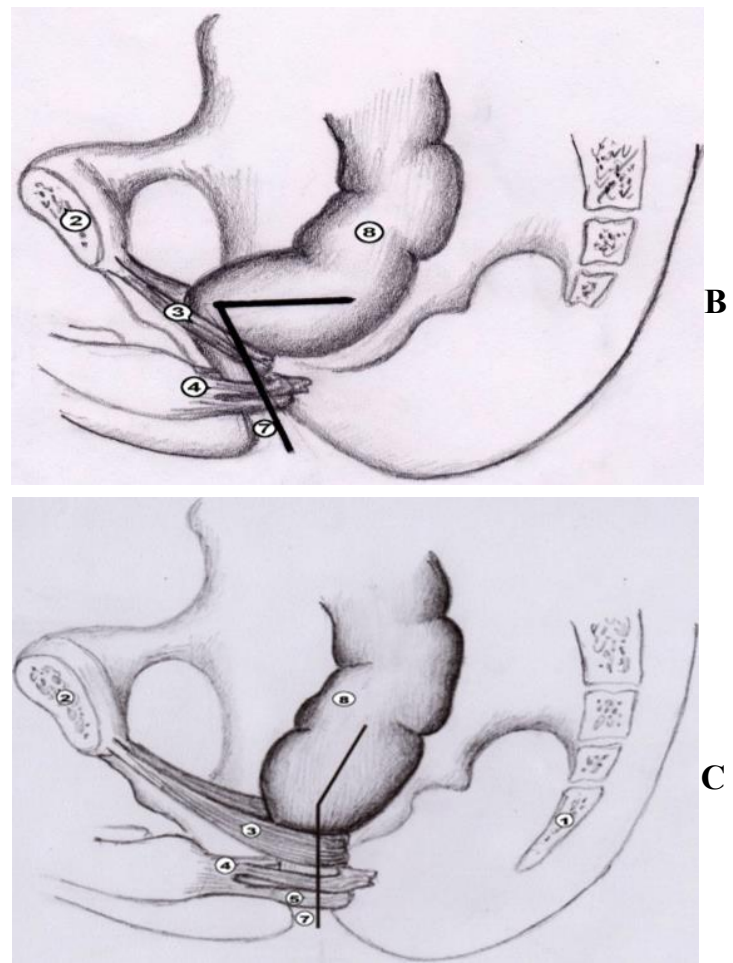

Fig. 8. Schematic representation of the outer muscle - sphere of the anus and and the external muscles of the anus: $A$ - normal: 1 - coccyx; 2 - pubic bone; 3 - pubic rectal muscle; 4 - superficial part of an external muscle - sphere of the anus; 5 - subcutaneous part of the outer muscle - sphere of the anus; 6 - anococcygeal ligament; 7 - anus; 8 - rectum: A - ARC is normal; $B$ - decreasing and $C$ - increasing ARC value in the destruction of the $A C L$ 


\section{Influence of the state of the anococcygeal ligament on the function of the sphincteric apparatus of the anus and the distal parts of the colon}

The pelvic diaphragm muscles form the lift muscle of the anus, and the ACL is woven into the fibers of the sphincter of the rectum (R), thus determining the dimensional configuration of the anorectum, due to the tract-contraction mechanism of the anal continence, that is, the compression and displacement of the $\mathrm{R}$, which is realized its displacement relative to the fixation of the points to the pelvic bone ligament. Therefore, any intervention that is accompanied by the removal of even a small component of the given complex, leads to disruption of the continent function after surgery ${ }^{5}$. In addition, after the removal of the coccyx, a residual cavity is formed at the site of the latter - a perineal-coccygeal fossa that can serve as the site of formation of inflammatory foci. But the main thing is that after a coccygectomy, which can be performed in a wide range of surgical, orthopedic and oncological pathology, ACL remains without the fixation point - the last coccygeal vertebra, which leads to pathological changes in the anatomical and functional factors that provide $\mathrm{R}$ defecation.

Determination of functional disorders of the sphincter apparatus of the anus and DCP in 50 patients after the damage of the ACL, during the radiological examination of the distal spine, cancellation of the coccyx in patients was less than normal and was $116,1 \pm 3,1^{\circ}$ against $150,6 \pm 3,7^{\circ}$ normal $(\mathrm{p}<0.01)$, which indicated reducing ACL elasticity and as a consequence of a change in ano-rectal angle (ARA).

The leading complaints in patients were coccidia, which increased in the sitting position, and at $20(40.0 \%)$ had irradiation in the lumbosacral department and at $8(16.0 \%)$ in the lower extremities, chronic defecation disorder in $12(24.0 \%)$ patients in observation period up to 2 years after the injury. Operative treatment, surgical removal of the coccyx was performed in $15(30.0 \%)$ children. In the postoperative period $9(60.0 \%)$ children complained on a difficult and prolonged act of defecation, which did not bring a feeling of complete emptying of the R, and in 4 (26.66\%), within the period of observation from 6 months to 1 year after the surgery, the phenomena of the encopresis of I - II grades were periodically noted.

To correct possible pathological conditions by creating conditions for the functional existence of the physiological value of the ARA, after the destruction of the ACL, the method of restoring of its functional capacity

5 Магнито-резонансное отображение повреждений удерживающих структур аноректума после онкопроктологических операций / Г.В. Бондарь, В.Х. Юашеев, О.В. Совпель, И.В. Совпель. Хірургія України. 2013. № 3. С. 60. 
was offered (Patent of Ukraine for the invention No. 115,280 "Method of removal of the coccyx"), which was carried out as follows. The position of the patient on the abdomen with diluted lower extremities. After the processing of the surgical area with the antiseptic solution thrice in the coccyx projection, an angular section of the soft tissues is conducted; the coccyx is removed retrograde with the surrounding scar tissue after excision from the coccyx of the proximal part of the ACL. Then the marked and cut coccyx part of the anococcygeal ligament is fixed with the two $\mathrm{P}$ - like seams apply to the lateral parts of 5 sacral vertebra in the projection of sacral-coccygeal junction for the correction of ano-rectal angle value (fig. 9).

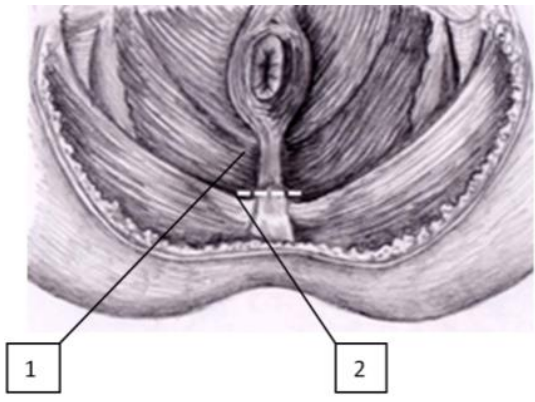

A

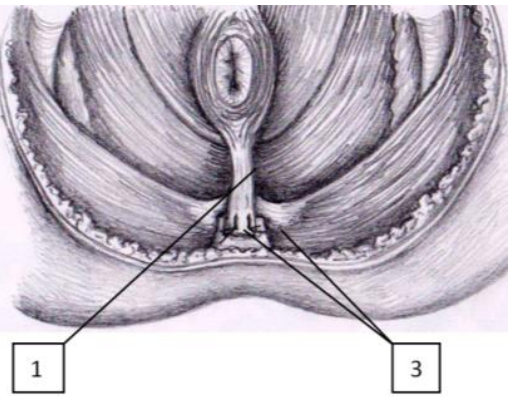

Б

Fig. 9. Operational scheme: A - general view of the ACL location; B - ACL plastic after the coccyx removing. 1 - anococcygeal ligament; 2 - conditional line of the amputation of anococcygeal ligament from the coccyx; 3 - "P" - similar seams

Clinical example: child C., 12 years old, MCIP № 14591 was hospitalized with the diagnosis of an ingrain fracture of the coccyx with displacement, with complaints of pain in the sacral-coccygeal spine, which is intensified by physical activity, sitting or squatting. It is known that about a year ago the child was injured during the fall. Over the last 6 months, the pain has increased, with the irradiation of the perineum, the phenomena of encopresis have appeared., Moderate pain is determined in the sacralcoccygeal area during palpation, movements in this section of the spine are somewhat limited and painful. Rectal finger examination determines the decreasing in the tone of the anal sphincters, widening the anus canal. After performing the radiographic examination of the sacral - coccygeal section in lateral projection: deformation of the coccyx, reduction of the sacral coccygeal angle to $118^{\circ}$, widening of the anus canal (fig. 10). 
The child underwent the surgery: Removal of the coccyx, plastic of the anococcygeal ligament. After processing of the operative area in the projection of the coccyx, an angular section of soft tissues up to $6 \mathrm{~cm}$ long was performed, and a coccyx with with the surrounding scar tissue was retrogradely removed after excision of the ACL (fig. 11).

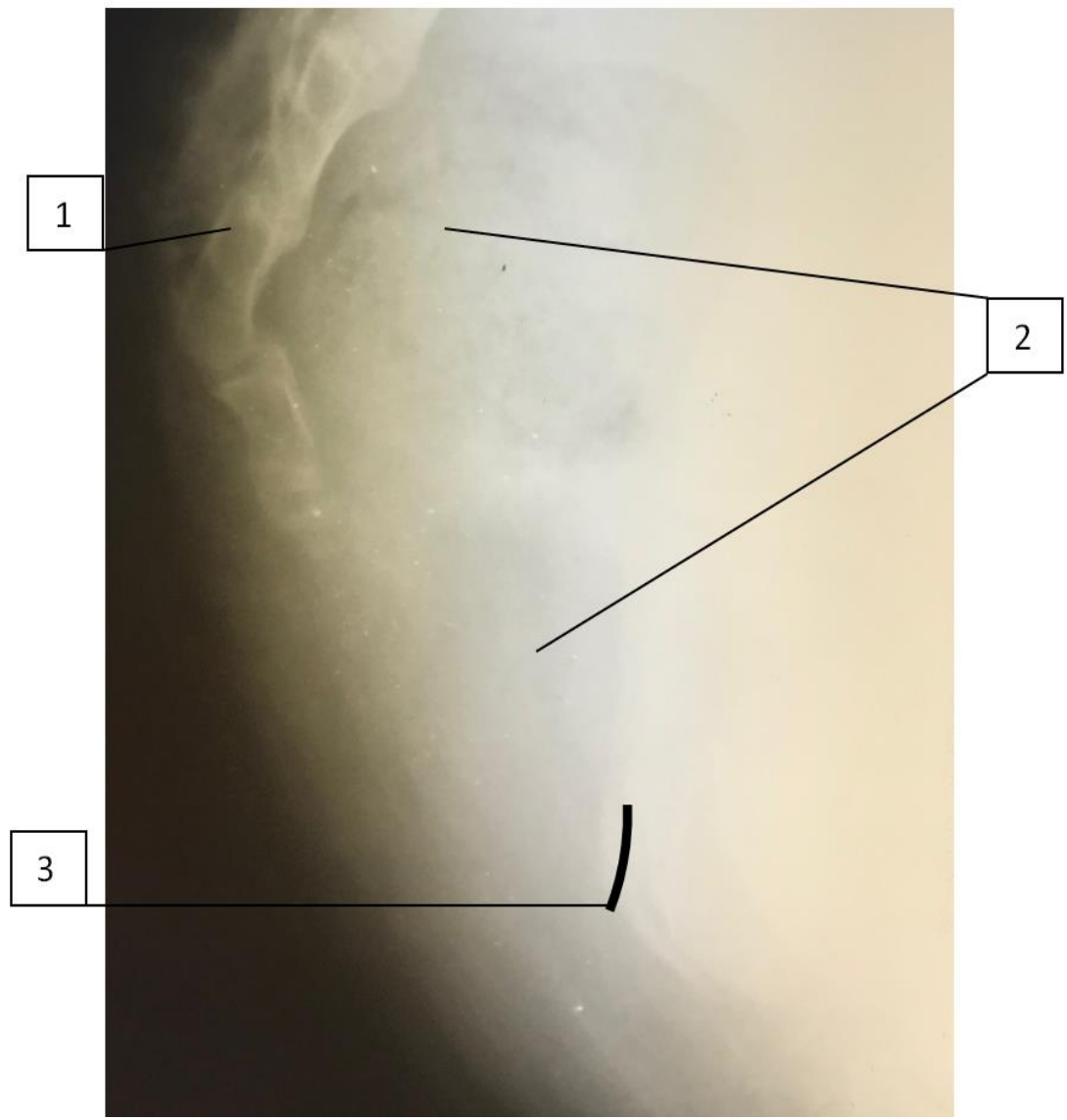

Fig. 10. Patient C., 12 years old, MCIP № 14591. Diagnosis: ingrain fracture of the coccyx with the displacement. Radiography of the sacral-coccygeal area in lateral projection: 1 - deformation of the coccyx at the site of its fracture; 2 - gas in the lumen of the rectum; 3 - the extended canal of the anus 


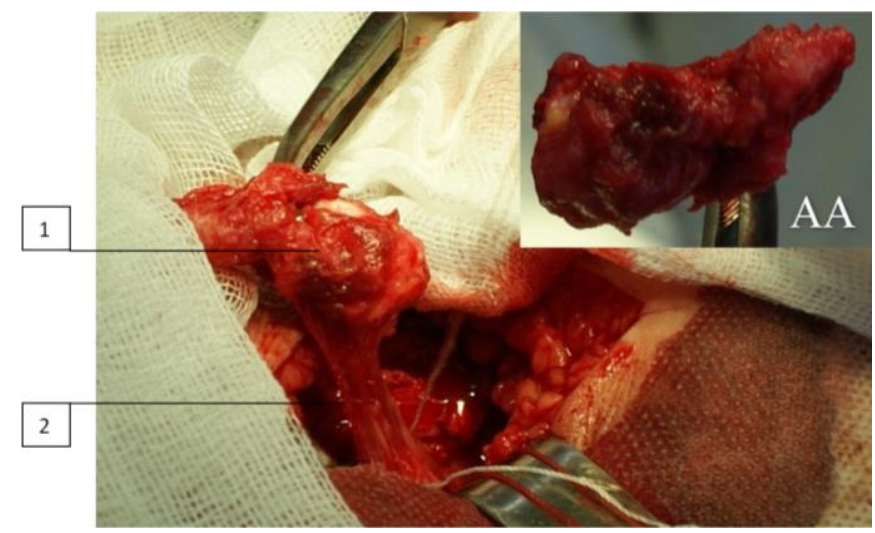

Fig. 11. Patient C., 12 years old, MCIP № 14591. Diagnosis: ingrain fracture of the coccyx with the displacement. Operational stages retrograde excision of the coccyx from the sacrum: 1 - coccyx;

2 - anococcygeal ligament; $\mathrm{AA}$ is a micropreparation of the removed coccyx

The marked coccygeal end of the ACL by applying two "P" - like seams is fixed to the lateral divisions of the $\mathrm{V}$ sacral vertebra in the projection of the sacral-coccygeal connection bond (fig. 12).

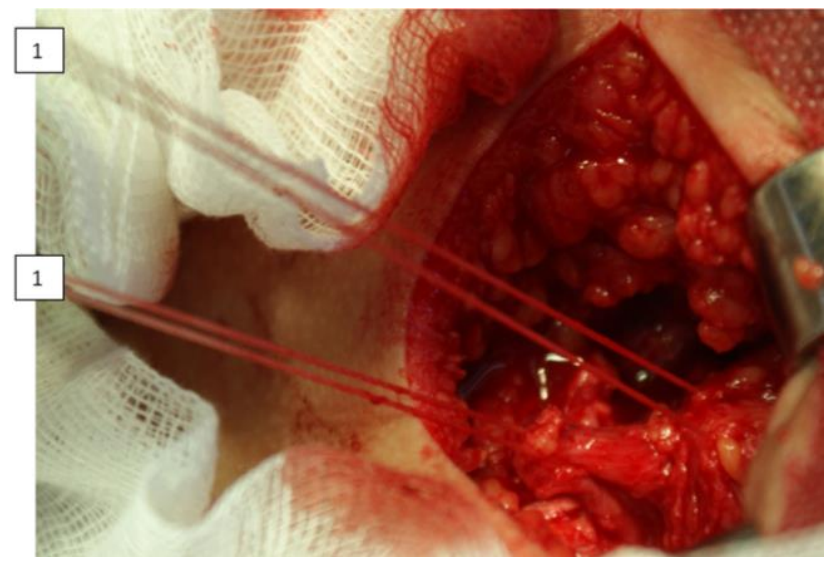

Fig. 12. Patient C., 12 years old, MCIP № 14591. Diagnosis: ingrain fracture of the coccyx with the displacement. Operational stages: applying of two "P" - like seams on the prepared lateral parts of the lateral divisions of distal parts $V$ of the sacral vertebra (1) 
The removed preparation of the coccyx with surrounding scar tissue (No. 55891 from 11/23/17), after the excision of the ACL, was undergone histological examination, during which certain degenerative changes were detected both from the bone tissue and from the side of the anococcygeal ligament (fig. 13).

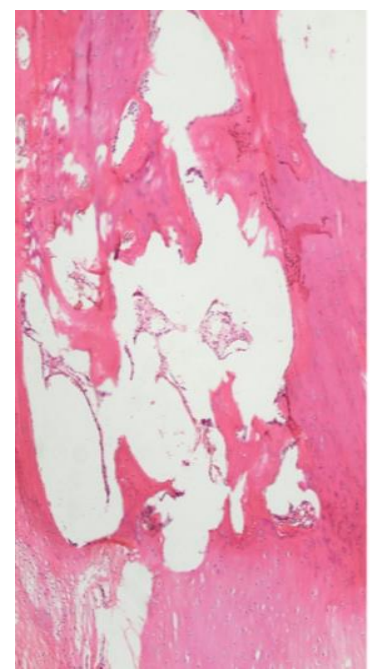

A

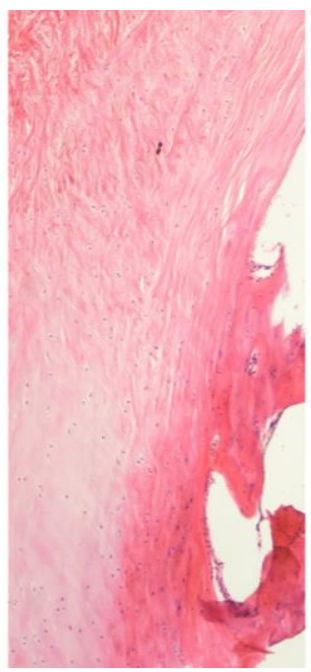

B

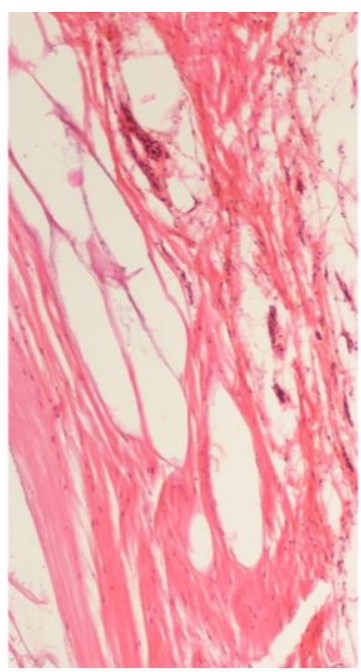

C

Fig. 13. Patient C., 12 years old, MCIP № 14591. Diagnosis: ingrain fracture of the coccyx with the displacement. Microphoto of a removed coccyx with surrounding scar tissue. A - a fragment of spongy bone with fibrosis of the intercostal space. The bone marrow is absent, replaced by loose fibrous tissue. Degenerative changes of bone (bone tissue of different density, with uneven location of osteoids and osteocytes); $B$ - fragment of the fibrous cartilage and bone beams with marked degenerative-dystrophic changes; $\mathrm{C}-\mathrm{a}$ fragment of $\mathrm{ACL}$ with its swelling, branching, homogenization of fibers of fibrous formed fibrous tissue, plethora of the vessels, site of ossification.

Hematoxylin and eosin coloring. $\times 100$

The postoperative period had a satisfactory course, discharged with recovery. Examined in 1 and 6 months after surgery, defecation and pain were absent.

Determined microscopically degenerative-dystrophic changes of various severity were characteristic in all clinical cases of ingrain coccyx injury, 
especially in combining of the clinical picture of pain syndrome with the phenomena. This fact, from our viewpoint, demonstrates the benefit of determining of the the indication for ACL plastic in patients with ingrain coccygeal injury.

\section{Intraoperative ACL plastic}

Intraoperative ACL plastic according to the offered method was performed in 15 patients: 12 children with post-traumatic injury of the coccyx; 3 patients with tumors of the pelvic organs and sacral coccygeal area that required intraoperative removal of the coccyx.

Taking into account the revealed dystrophic changes in the morphological structure of the bone and ligament elements of the coccyx and considering the existing phenomena of encopresis in a certain part of patients after the injury of the coccyx, the influence and efficacy of ACL plastic was researched by studying the anorectal manometry values of two supervising groups; Group I - children without the ACL plastic; Group II children with ACL plastic in pre- and postoperative periods (table 1).

Table 1

The values of anorectal manometry in both comparison groups

\begin{tabular}{|c|c|c|c|c|c|c|c|}
\hline \multirow[b]{2}{*}{ Indicator } & \multirow{2}{*}{$\begin{array}{c}\begin{array}{c}\text { Control } \\
\text { group }\end{array} \\
(n=28)\end{array}$} & \multicolumn{3}{|c|}{$\begin{array}{l}\text { Children without plastic } \\
\text { of ACL } I(n=15)\end{array}$} & \multicolumn{3}{|c|}{$\begin{array}{l}\text { Children with plastic } \\
\text { of ACL II }(n=15)\end{array}$} \\
\hline & & $\begin{array}{l}\text { Before } \\
\text { surgery }\end{array}$ & $\begin{array}{c}\text { In } 6 \\
\text { months }\end{array}$ & $\begin{array}{l}\text { In } 12 \\
\text { months }\end{array}$ & $\begin{array}{l}\text { Before } \\
\text { surgery }\end{array}$ & $\begin{array}{c}\text { In } 6 \\
\text { months }\end{array}$ & $\begin{array}{c}\text { In } 12 \\
\text { months }\end{array}$ \\
\hline $\begin{array}{l}\text { Basal } \\
\text { pressure } \\
\text { of BCB } \\
(\mathrm{mmHg}) \\
\end{array}$ & $62.8 \pm 1.6$ & $44.1 \pm 1.3$ & $48.4 \pm 1.6$ & $49.8 \pm 1.8$ & $43.3 \pm 0.8$ & $55.1 \pm 0.9$ & $58.6 \pm 0.4$ \\
\hline $\mathrm{p}$ & & $<0.05$ & $<0.05$ & $<0.05$ & $<0.05$ & $<0.05$ & $<0.05$ \\
\hline $\begin{array}{c}\text { Recto-anal } \\
\text { reflex } \\
(\mathrm{mmHg})\end{array}$ & $21.2 \pm 1.2$ & $14.7 \pm 0.7$ & $15.8 \pm 0.8$ & $\begin{array}{l}16.3 \pm \\
0.9\end{array}$ & $15.1 \pm 0.7$ & $19.6 \pm 0.8$ & $20.9 \pm 1.1$ \\
\hline $\mathrm{p}$ & & $<0.05$ & $<0.05$ & $<0.05$ & $<0.05$ & $>0.05$ & $>0.05$ \\
\hline \begin{tabular}{|c} 
Rectal \\
tolerance $(\mathrm{ml})$ \\
\end{tabular} & $26.8 \pm 1.3$ & $\begin{array}{c}1158.5 \pm \\
8.6\end{array}$ & $\begin{array}{c}156.2 \pm \\
7.7 \\
\end{array}$ & $\begin{array}{c}1112.3 \pm \\
4.8 \\
\end{array}$ & $\begin{array}{c}146.2 \pm 6 . \\
11\end{array}$ & $\begin{array}{c}53.1 \pm \\
3.4 \\
\end{array}$ & $\begin{array}{c}29.6 \pm \\
0.8\end{array}$ \\
\hline $\mathrm{p}$ & & $<0.05$ & $<0.05$ & $<0.05$ & $<0.05$ & $<0.05$ & $>0.05$ \\
\hline
\end{tabular}

Note: $\mathrm{p}$ - the veracity of the difference between the studied indicators and the control group 
The basal pressure value of the internal sphincter of the anus (ISA) in the group of children who weren't undergone the ACL plastic, during the whole observation did not tend to normalize, and even in 12 months of supervision was significantly less than normal, respectively, $49.8 \pm 1.8 \mathrm{~mm} \mathrm{Hg}$. against $62.8 \pm 1.6 \mathrm{~mm} \mathrm{Hg}$. (p < 0.05).

At children, after ACL plastic, the tendency to normalization of the value of basal pressure of ACL was determined during the whole period of observation, which in 12 months after the surgery, approached the norm as closely as possible, respectively $58.6 \pm 0.4 \mathrm{~mm} \mathrm{Hg}$. against $62.8 \pm 1.6 \mathrm{~mm}$ Hg. of normal ( $\mathrm{p}<0.05)$.

The value of basal blood pressure of ISA at children of group I in 12 months after the surgery was $27.7 \%$ lower than normal, while at children of group II, the indicator had a more marked tendency to increase during the whole period of observation. So, after 12 months from the moment of performing intraoperative fixation of the ACL, the value of the basal pressure of the ISA was lower than normal only for $6.7 \%$. Comparing the values of basal blood pressure of ISA in both groups in 12 months after surgery, it should be noted that in children of group II the required interval of time to complete normalization of the index was 4.13 times smaller comperatively to the children of the group I. The value of the recto-anal reflex in Group I did not have a clear tendency to the indicator normalization during the whole observation period. In 12 months after surgery, the value of the recto-anal reflex was only $16.3 \pm 0.9 \mathrm{~mm} \mathrm{Hg}$. against $21.2 \pm 1.2 \mathrm{~mm} \mathrm{Hg}$. of normal ( $\mathrm{p}<0.05$ ). Instead of, in group II a clear tendency to the indicator normalization was observed during the whole observation period, which in 12 months of supervising was $20.9 \pm 1.1 \mathrm{~mm} \mathrm{Hg}$. against $21.2 \pm 1.2 \mathrm{~mm} \mathrm{Hg}$. of normal ( $p>0.05$ ). The value of recto-anal reflex in the children of group I during the whole observation periods had a slight positive dynamics, the increasing of the indicator in 12 months was only $9.82 \%$, and in general it was less than the norm by $23.1 \%$. Increasing of the value of recto-anal reflex in children of the group II during the whole observation period was more active, and in 12 months its value was only $1.4 \%$ lower than normal. In 12 months after the surgery, the children of the group II had an interval of 16.5 times less than the patients of the group I before their full normalization.

The value of the rectal tolerance sensitivity in the first group of children did not have a clear tendency to normalize, and even in 12 months after the surgery was significantly higher than normal, $112.3 \pm 4.8 \mathrm{ml}$ against $26.8 \pm 1.3 \mathrm{ml}(\mathrm{p}<0.01)$ respectively. In the second group of children, the value of the rectal tolerance sensitivity during the whole observation period, had the marked tendency to its decreasing, and which up to 12 months after 
ACL plastic was as close as possible to the norm, $29,6 \pm 0,8 \mathrm{ml}$ against $26,8 \pm 1,3 \mathrm{ml}(\mathrm{p}>0.05)$ respectively. The tolerance of rectal sensitivity at children of the group I decreased by only $1.4 \%$ in 6 months after the surgery, and in 12 months the value of the indicator was $76.1 \%$ higher than normal, however, the dynamics of the value of the tolerance of rectal sensitivity at children of the group II had a clear tendency to its decreasing during the whole observation period. In 12 months after the ACL plastics, the value of the index was only $9.5 \%$ higher than normal. Assessment of the value of the rectal tolerance sensitivity at children of both groups in 12 months after the surgery determined that at patients after the ACL plastic, the required time interval to complete normalization of the indicator was 8 times smaller than at group I.

Studies have shown that an important component of the prevention of the defecation disorders at patients with ACL damage, should be intraoperative elimination of the rectum-coccygeal cavity with the ACL plastic to restore the integrity of the musculoskeletal system of the pelvic bottom by the way of rehabilitation its anatomical fixation.

\section{CONCLUSIONS}

Any damaging effect in the area of the tract-contraction mechanism of action on the rectum, which is accompanied by even its minimal destruction in $90.0 \%$ leads to the formation of disturbances of the continent due to the value changes of the ano-rectal angle, because of the emergence of the persistent disorders of the function of the anococcygeal ligament. The obtained data and the created spatial mathematical model of the anococcygeal ligament function, indicate that during its destruction the change of the value of ano-rectal angle can reach its value change up to $\approx 63^{\circ}$, which create the direction of the anal canal and distal part of the rectum. Recovery by simulating of the anatomical fixation of the junction of the anococcygeal ligament after its intraoperative destruction or damage allows to create conditions for the restoration of its physiological functioning, which in its turn, contributes to the prevention of defecation disorders.

\section{SUMMARY}

The work is based on the results of the examination and treatment of 271 patients with defecation disorders, 114 (42,1\%) boys, (57,9\%) girls who were treated at the surgical departments of the pediatric surgery clinic of National Pirogov Memorial Medical University, Vinnytsia in the period from 2008 to 2018, and were residents of Podilskyi ethnic territorial region, which determined the unity of the peculiarities of life and nutrition.

In order to prevent and correct the defecation disorders after destruction of the anococcygeal ligament, the method of restoring its functional capacity 
was proposed (Patent of Ukraine for Invention No. 115280 "Method for Coccyx Removing").

It is proved that the damaging effect in the area of the traction and contraction mechanism of action on the rectum in $90,0 \%$ leads to continence disorders due to changes in the size of the anorectal angle due to the persistent disorders of the anococcygeal ligament function. The developed spacial mathematical model of the anococcygeal ligament function testifies that, when it is destroyed, the change in the anorectal angle value may reach changes in its value up to $\approx 63^{\circ}$, which distorts the direction of the anal canal and the distal rectum. Restoration by simulating of the anatomical fixation of anococcygeal ligament connection after its damage creates conditions for restoration of its physiological functioning.

\section{REFERENCES}

1. Васильчишина А.В., Хмара Т.В., Васильчишина Я.М. Перинатальна анатомія сідничної ділянки. Чернівці : Медуніверситет, 2017. $220 \mathrm{c}$.

2. Бабкин А.В., Егорова 3.В. Современные подходы к лечению кокцигодинии. ARS MEDICA. 2012. № 4, т. 59. С. 3-11.

3. Клінічна анатомія прямої кишки та відхідника / Слободян О.М., Костюк Г.Я., Дуденко В.Г. та ін. Чернівці, 2015. 180 с.

4. Конопліцький В.С. Модель хвильового процесу вмісту прямої кишки під дією перистальтичних рухів. Наукові записки міжнародного гуманітарного університету. 2014. Вип. 21, Ч. II.16. С. 182-187.

5. Магнито-резонансное отображение повреждений удерживающих структур аноректума после онкопроктологических операций / Г.В. Бондарь, В.Х. Юашеев, О.В. Совпель, И.В. Совпель. Хірургія України. 2013. № 3. С. 59-64.

Information about authors:

Konoplitskyi V.S., MD, Professor,

Head the Department of Pediatric Surgery

National Pirogov Memorial University

56, Pyrogov str., Vinnytsia, 21018, Ukraine

Lukiianets O. O.,

Candidate of Medical Sciences, Associate Professor of the Department of Pediatric Surgery

National Pirogov Memorial University 56, Pyrogov str., Vinnytsia, 21018, Ukraine 